\title{
Antimicrobial Activity of Miconia Species (Melastomataceae)
}

\author{
Juliana Rodrigues, ${ }^{1}$ Danielle Carvalho Michelin, ${ }^{2}$ Daniel Rinaldo, ${ }^{1}$ Guilherme Julião Zocolo, ${ }^{3}$ \\ Lourdes Campaner dos Santos, ${ }^{1}$ Wagner Vilegas, ${ }^{1}$ and Hérida Regina Nunes Salgado ${ }^{2}$ \\ Departments of ${ }^{1}$ Organic Chemistry and ${ }^{3}$ Analytical Chemistry, Institute of Chemistry, \\ and ${ }^{2}$ Department of Drugs and Medicines, Faculty of Pharmaceutical Sciences, \\ São Paulo State University, Araraquara, São Paulo, Brazil
}

\begin{abstract}
This work evaluated the antimicrobial activity of the methanol and chloroform extracts of the leaves of $M i$ conia cabucu, Miconia rubiginosa, and Miconia stenostachya using the disc-diffusion method. The results obtained showed that the methanol extracts of the leaves of M. rubiginosa and M. stenostachya and the chloroform extract of the leaves of $M$. саbиси presented antimicrobial activity against the tested microorganisms.
\end{abstract}

KEY WORDS: • disc-diffusion method • Miconia cabucu • phenolic compounds

\section{INTRODUCTION}

$\mathbf{S}^{\mathrm{s}}$ ECONDARY METABOLITES produced by plants constitute a source of bioactive substances. Nowadays, scientific interest in these metabolites has increased because of the search for new drugs originating from plants. Miconia is a genus belonging to the family Melastomataceae, which is a pantropical family with over 166 genera that include about 4,300 species. ${ }^{1}$ Many of these plants are used for medicinal purposes by people living in the Cerrado lands. ${ }^{2}$ In many parts of Brazil, there is a tradition of using herbal medicines for the treatment of infectious diseases. Miconia infusions, extracts, and isolated compounds have demonstrated biological activities such as antibiotic, antitumoral, analgesic, and antimalarial effects. 3,4

Previous phytochemical investigations of Miconia species have resulted in the isolation of triterpenes, ${ }^{5,6}$ flavonoids (J. Rodrigues et al., unpublished data), ${ }^{7,8}$ a quinone, and quinol compounds. ${ }^{9}$

The present study has as its aim the evaluation of the antimicrobial activity of Miconia cabucu, Miconia rubiginosa, and Miconia stenostachya extracts obtained from their leaves using the disc-diffusion method. A phytochemical screening of the chloroform extracts and also a phytochemical study of the methanol $(\mathrm{MeOH})$ extracts of the leaves were done.

Manuscript received 17 August 2007. Revision accepted 1 October 2007.

Address reprint requests to: Profa. Dra. Lourdes Campaner dos Santos, Departamento de Química Orgânica, Instituto de Química de Araraquara, São Paulo State University, Universidade Estadual Paulista Rua Prof. Francisco Degni $s / n$, Bairro Quitandinha, CEP 14800-900, Araraquara, SP, Brazil, E-mail: loursant@iq.unesp.br

\section{MATERIALS AND METHODS}

\section{Biological material}

Nine microbial species taken from international collections were analyzed: the bacteria Bacillus subtilis (ATCC 9372), Bacillus cereus (ATCC 14579), Staphylococcus epidermidis (ATCC 12228), Staphylococcus aureus (ATCC6538), Salmonella spp. (ATCC 19196), Enterococcus faecalis (ATCC 29212), Escherichia coli (ATCC 10536), and Micrococcus luteus (ATCC9341) and the yeast Candida albicans (ATCC 64550).

\section{Apparatus}

The high-performance liquid chromatography (HPLC) analyses were performed with a liquid chromatograph equipped with a ProStar 210 dual solvent pump, a ProStar 330 photodiode array detector (Varian, Walnut Creek, CA), and a Rheodyne (Cotati, CA) model 7125 sample injector with a $20-\mu \mathrm{L}$ sample loop. The column was a Phenomenex (Torrance, CA) Luna $\mathrm{C}_{18}(250 \times 4.6 \mathrm{~mm}$ i.d.; particle size $5 \mu \mathrm{m})$ equipped with a Phenomenex Security Guard $(4.0 \times$ $2.0 \mathrm{~mm}$ i.d.). The mobile phase was $\mathrm{H}_{2} \mathrm{O}+0.05 \%$ trifluoroacetic acid (eluent $\mathrm{A}$ ) and $\mathrm{CH}_{3} \mathrm{CN}+0.05 \%$ trifluoroacetic acid (eluent B). The gradient program was $32-35 \%$ B for 20 minutes, $35-75 \%$ B for 60 minutes, and $75-100 \%$ B for 65 minutes, eluted at a flow rate of $1.0 \mathrm{~mL} /$ minute. Star LC Workstation software was used both for the operation of the detector and for data processing. Gas chromatography (GC)flame ionization detector (FID) analyses were performed using a Varian CP 3380 gas chromatograph equipped with a fused silica DB-5 capillary column $(15 \mathrm{~m} \times 0.2 \mathrm{~mm}$ i.d.; film thickness $0.2 \mu \mathrm{m}$ ) and an FID. Nitrogen was used as 
the carrier gas, and the injection-split ratio was 1:20. The injection temperature was $280^{\circ} \mathrm{C}$; the column temperature was held at $35^{\circ} \mathrm{C}$ for 2 minutes and then increased to $310^{\circ} \mathrm{C}$ at $8^{\circ} \mathrm{C} /$ minute, and this temperature was held for 5 minutes; and the detector temperature was $280^{\circ} \mathrm{C}$. Samples of $2 \mu \mathrm{L}$ were injected using a $10-\mu \mathrm{L}$ Hamilton (Reno, NV) syringe. GC-mass spectrometry (MS) analyses were performed on a Varian CP 3800 gas chromatograph coupled with an ion trap Varian Saturn 2000 gas chromatograph-tandem mass spectrometer, a Varian CP 8200 autosampler, the Star Workstation Data System, and the NIST05 libraries (Varian). A Factor Four VF-5MS (DB5) fused silica capillary column (30 $\mathrm{m} \times 0.25 \mathrm{~mm}$ i.d.; particle size $0.25 \mu \mathrm{m}$ ) (Varian) was used. Helium was used as carrier gas (purity $>99.995 \%$ ). The GC oven temperature was initially held at $45^{\circ} \mathrm{C}$ for 2 minutes, then increased to $310^{\circ} \mathrm{C}$ at $8^{\circ} \mathrm{C} /$ minute, and held for $5 \mathrm{~min}$ utes. The injection temperature was $260^{\circ} \mathrm{C}$ and split 1:50. Injection volume was $1 \mu \mathrm{L}$. Helium was used as carrier gas with a constant flow rate of $1.0 \mathrm{~mL} /$ minute. The mass-selective detector was operated in electron ionization mode with $70 \mathrm{eV}$ of electron energy. The ion source temperature was $200^{\circ} \mathrm{C}$, and the GC-MS interface temperature was $220^{\circ} \mathrm{C}$. Full scan and MS/MS scan mode were selected. Full scan mode was chosen with a wide range of $\mathrm{m} / \mathrm{z}$ (40-600) and a solvent cutoff time of 3.0 minutes.

\section{Plant material}

Aerial parts of M. cabucu were collected in April 2005 at Pariquera-Açu, in the state of São Paulo, Brazil, and authenticated by Prof. Dr. Jorge Yoshio Tamashiro from the Instituto de Biologia, UNICAMP, São Paulo State University, Campinas, SP, Brazil. A voucher specimen (number 1430) has been deposited in the Herbarium of the Universidade Estadual de Campinas, Brazil. Aerial parts of $M$. rubiginosa and M. stenostachya were collected in March 2005 at Palmeiras da Serra, Pratânia, SP, Brazil and authenticated by Dr. Luiz Fernando Rolim de Almeida from the Instituto de Botânica, São Paulo State University. Voucher specimens (numbers 25376 and 25377, respectively) were deposited at the Herbarium "Irina Delanova Gemtchujnicov" BOTU of the Instituto de Biociências, São Paulo State University, Botucatu, SP, Brazil.

\section{Preparation of extracts}

The dried leaves of $M$. cabucu, M. rubiginosa, and $M$. stenostachya (600 g, $500 \mathrm{~g}$, and $500 \mathrm{~g}$, respectively) were separated, powdered, and extracted exhaustively at room temperature with $\mathrm{CHCl}_{3}(2 \mathrm{~L})$ and $\mathrm{MeOH}(3 \mathrm{~L}), 1$ week for each solvent. Solvents were evaporated at $35^{\circ} \mathrm{C}$ under re-

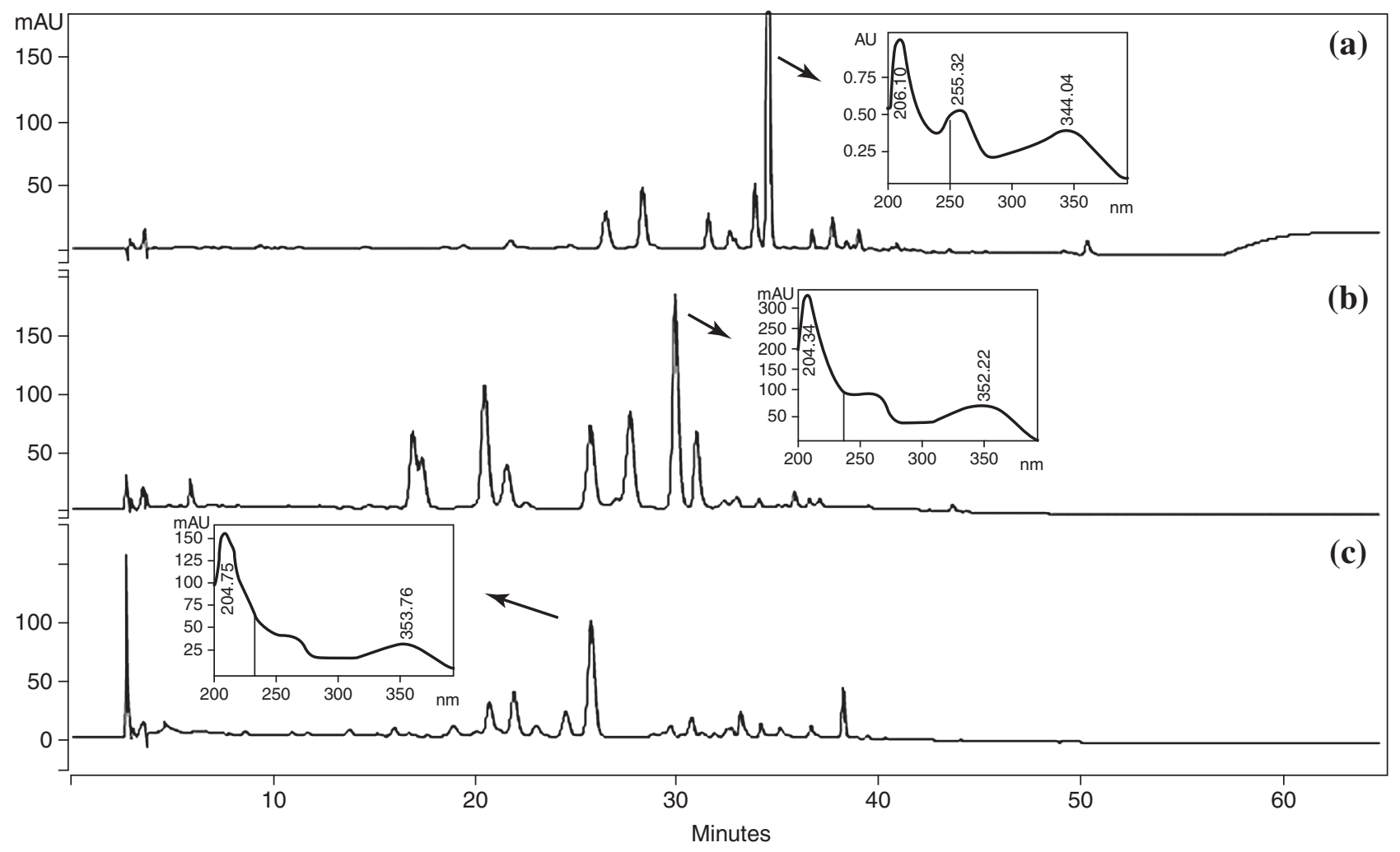

FIG. 1. Profiles of the $\mathrm{MeOH}$ extracts of (a) M. cabucu, (b) M. rubiginosa, and (c) M. stenostachya $(\mathrm{RP}-18 ; 250 \times 4.60 \mathrm{~mm}$ i.d.; particle size $5 \mu \mathrm{m})$. Solvent A was $\mathrm{H}_{2} \mathrm{O}+0.05 \%$ trifluoroacetic acid; solvent B was $\mathrm{CH}_{3} \mathrm{CN}+0.05 \%$ trifluoroacetic acid. The gradient was $32-35 \%$ B for 20 minutes, $35-75 \%$ B for 60 minutes, and $75-100 \%$ B for 65 minutes at a flow rate of $1.0 \mathrm{~mL} /$ minute $(\lambda=254 \mathrm{~nm})$. (Insets) Some ultraviolet spectra from peaks. AU, arbitrary units. 
duced pressure to afford the $\mathrm{CHCl}_{3}$ extract $(14.0 \mathrm{~g}, 15.9 \mathrm{~g}$, and $16.2 \mathrm{~g}$, respectively) and $\mathrm{MeOH}$ extract $(20.0 \mathrm{~g}, 46.7 \mathrm{~g}$, and $72.9 \mathrm{~g}$, respectively).

\section{Phytochemical study of $\mathrm{MeOH}$ extracts}

For this phytochemical examination, we used samples of the $\mathrm{MeOH}$ extract of Miconia leaves. Thin-layer chromatography (TLC) plates on glass $(20 \mathrm{~cm} \times 20 \mathrm{~cm}$, Aldrich, Milwaukee, WI) were developed with a solvent mixture composed of $/ \mathrm{MeOH} / n-\mathrm{PrOH} / \mathrm{H}_{2} \mathrm{O}$ (5:6:1:4, by volume) and compared with authentic standards available in our laboratory. The plates were observed under ultraviolet (UV) light and were sprayed with anisaldehyde/sulfuric acid solution and natural products/polyethyleneglycol (NP/PEG) reagent, indicating that this polar extract contained flavonoids derived from quercetin, kaempferol, catechin and gallic acid derivatives, and tannins. The $\mathrm{MeOH}$ extracts were obtained after a solid-phase extraction in a Sep Pak $\mathrm{C}_{18}$ cartridge (20 mg, Waters, Milford, MA). The cartridge was preconditioned with $10 \mathrm{~mL}$ of $\mathrm{MeOH}$ and $10 \mathrm{~mL}$ of HPLC-grade $\mathrm{H}_{2} \mathrm{O}(18 \mathrm{~m} \Omega / \mathrm{cm})$ obtained from a Millipore (Bedford, MA) Milli-Q purification system. A suitable amount of sample (to load $20 \mathrm{mg}$ of extract/g of solid phase) was loaded onto the $\mathrm{C}_{18}$ cartridge. The sample adsorbed was eluted with 15
$\mathrm{mL}$ of $\mathrm{H}_{2} \mathrm{O}-\mathrm{MeOH}$ (8:2, fraction 1), $15 \mathrm{~mL}$ of $\mathrm{H}_{2} \mathrm{O}-\mathrm{MeOH}$ (1:1, fraction 2), and $\mathrm{MeOH} 100 \%$ (fraction 3) and was dried using a stream of $\mathrm{N}_{2}$. The residues of the three fractions were redissolved in $2 \mathrm{~mL}$ of $\mathrm{MeOH}$ and filtered through a $0.45-\mu \mathrm{m}$ (pore size) membrane polytetrafluoroethylene filter (Millex ${ }^{\mathrm{TM}}$, Millipore), and then $20 \mu \mathrm{L}$ of this filtrate was subjected to HPLC-UV-photodiode array analysis. UV spectra of some peaks presented bands at 255 and $350 \mathrm{~nm}$ typical of flavonoid derivatives, whereas other peaks presented bands at 204 and $280 \mathrm{~nm}$ characteristic of catechin derivatives, ${ }^{10}$ as exemplified in Figure 1.

\section{Preliminary study of $\mathrm{CHCl}_{3}$ extracts}

The chloroform extracts were studied using TLC, GCFID, and GC-MS. The extracts were analyzed using silica gel TLC plates on glass $(20 \mathrm{~cm} \times 20 \mathrm{~cm}$, Aldrich $)$ developed with a solvent mixture composed of hexane:ethyl acetate $(9: 1, \mathrm{vol} / \mathrm{vol})$ with standards of apolar substances as terpenoids and steroids. This permitted us to suggest the presence of lupeol and $\alpha, \beta$-amirin triterpenes because of the similarity in their retention times when compared with the standards used. The $\mathrm{CHCl}_{3}$ extracts were subjected to liquid chromatography with silica-gel $60(10 \times 10 \mathrm{~cm})$, eluted with hexane, $\mathrm{CHCl}_{3}$, and $\mathrm{MeOH}$. The hexane fraction $(0.5$

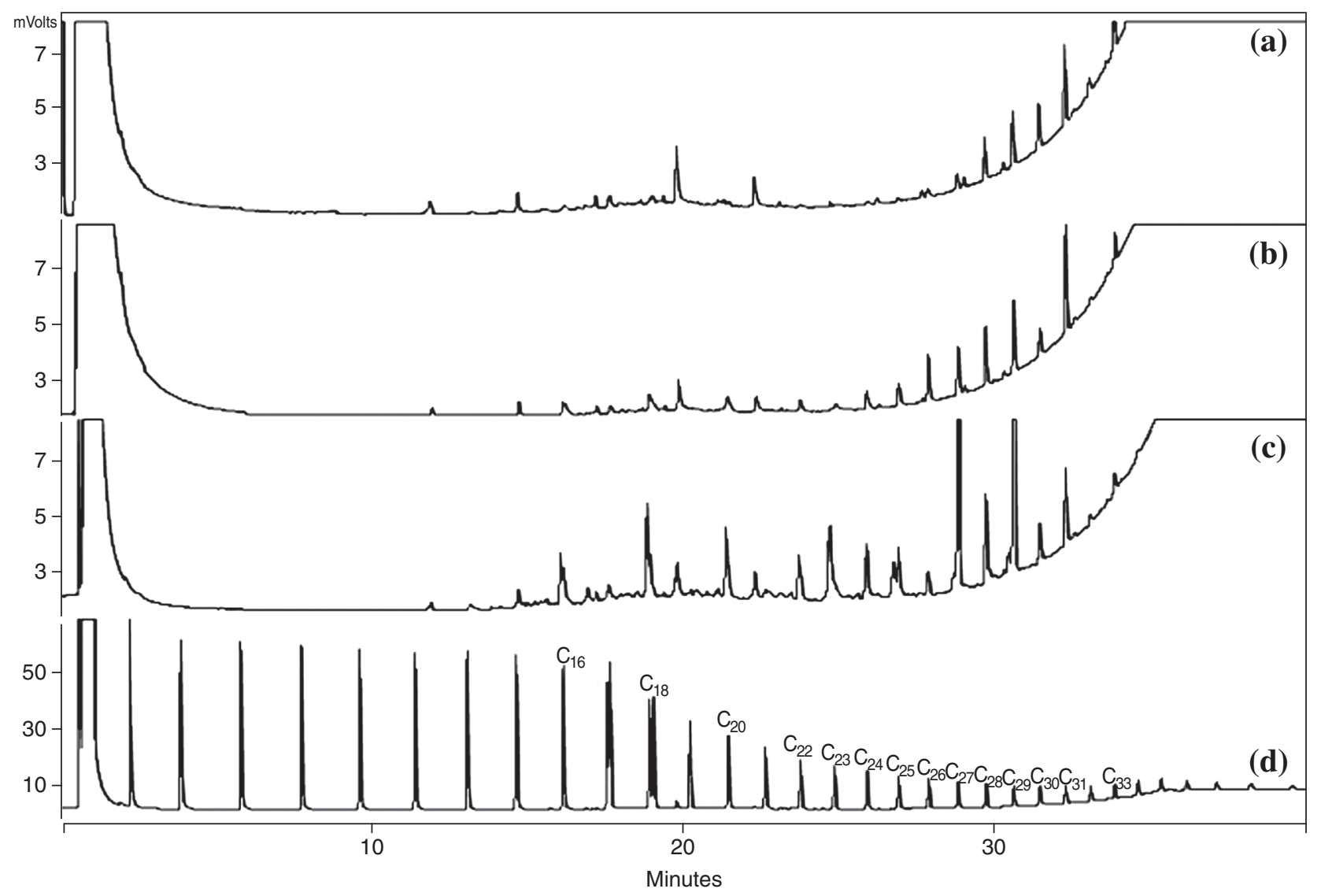

FIG. 2. GC-FID chromatograms of (a) M. cabucu, (b) M. rubiginosa, (c) M. stenostachya, and (d) hydrocarbon standards (Sigma). 


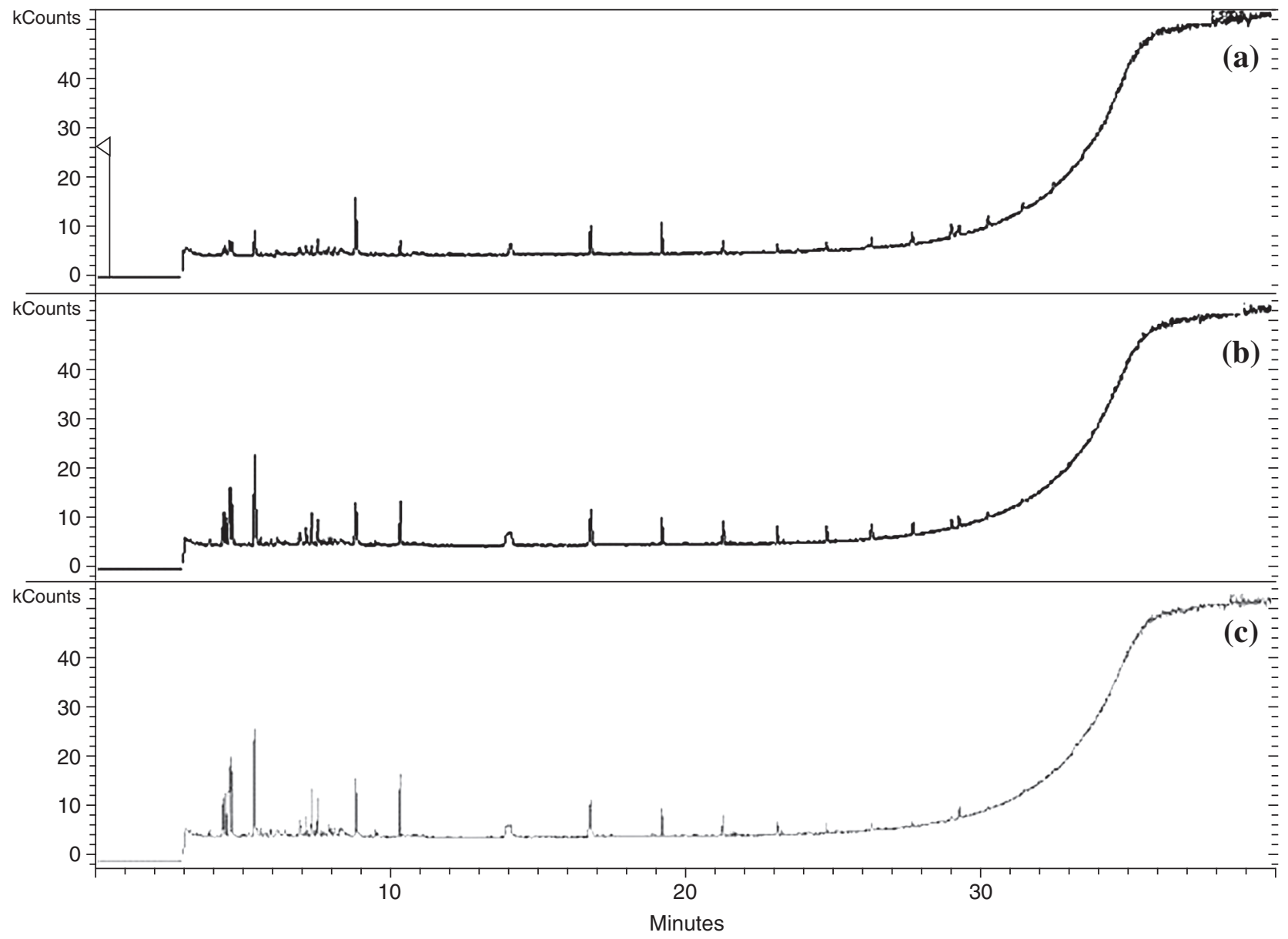

FIG. 3. GC-MS chromatograms of (a) M. cabucu, (b) M. rubiginosa, and (c) M. stenostachya.

$\mathrm{mg}$ ) was dissolved in $1 \mathrm{~mL}$ of hexane and then analyzed using GC-FID with standards of $n$-alkanes (Sigma, St. Louis, MO) and GC-MS. By comparing the retention time $\left(R_{\mathrm{t}}\right)$ values of the extract peaks with those of the standards (Fig. 2), the presence of the following hydrocarbons were observed: $n$-hexadecane $\left(\mathrm{C}_{16} \mathrm{H}_{34}, R_{\mathrm{t}}=16.1\right.$ minutes $)$, n-octadecane $\left(\mathrm{C}_{18} \mathrm{H}_{38}, R_{\mathrm{t}}=18.9\right.$ minutes $), n$-eicosane $\left(\mathrm{C}_{20} \mathrm{H}_{42}, R_{\mathrm{t}}=21.4\right.$ minutes), n-docosane $\left(\mathrm{C}_{22} \mathrm{H}_{46}, R_{\mathrm{t}}=23.7\right.$ minutes $)$, $n$-tricosane $\left(\mathrm{C}_{23} \mathrm{H}_{48}, R_{\mathrm{t}}=24.8\right.$ minutes $), n$-tetracosane $\left(\mathrm{C}_{24} \mathrm{H}_{50}\right.$, $R_{\mathrm{t}}=25.8$ minutes $), n$-pentacosane $\left(\mathrm{C}_{25} \mathrm{H}_{52}, R_{\mathrm{t}}=26.9\right.$ minutes $), n$-hexacosane $\left(\mathrm{C}_{26} \mathrm{H}_{54}, R_{\mathrm{t}}=27.8\right.$ minutes $), n$-heptacosane $\left(\mathrm{C}_{27} \mathrm{H}_{56}, R_{\mathrm{t}}=28.8\right.$ minutes $), n$-octacosane $\left(\mathrm{C}_{28} \mathrm{H}_{58}\right.$, $R_{\mathrm{t}}=29.7$ minutes $), n$-nonacosane $\left(\mathrm{C}_{29} \mathrm{H}_{60}, R_{\mathrm{t}}=30.5\right.$ minutes $), n$-triacontane $\left(\mathrm{C}_{30} \mathrm{H}_{62}, R_{\mathrm{t}}=31.4\right.$ minutes $), n$-hentriacontane $\left(\mathrm{C}_{31} \mathrm{H}_{64}, R_{\mathrm{t}}=32.2\right.$ minutes $)$, and $n$-tritriacontane $\left(\mathrm{C}_{33} \mathrm{H}_{68}, R_{\mathrm{t}}=33.8\right.$ minutes $)$. General profiles for $\mathrm{CHCl}_{3}$ extracts were obtained using GC-MS (Fig. 3). The molecular ion peak of these metabolites has a low intensity. The largest peaks generally represent $\mathrm{C}_{n} \mathrm{H}_{2 n+1}, \mathrm{C}_{n} \mathrm{H}_{2 n}$, or $\mathrm{C}_{n} \mathrm{H}_{2 n-1}$ fragments. The most abundant fragments are at $\mathrm{C}_{3}$ and $\mathrm{C}_{4} \cdot{ }^{11}$ The M-15 peak is typical for branched alkanes, particularly if the side chain is a methyl group. In contrast, the loss of this group is not favored for $n$-alkanes. ${ }^{12}$ In the mass spectra ob- tained via GC-MS, peaks are observed having an $\mathrm{m} / \mathrm{z}$ of 41 , 43, and 57 in all chromatograms, as shown in Table 1. These peaks correspond to $\mathrm{C}_{3} \mathrm{H}_{5}, \mathrm{C}_{3} \mathrm{H}_{7}$, and $\mathrm{C}_{4} \mathrm{H}_{9}$ fragments, respectively.

\section{Disc-diffusion method}

The dried plant leaf extracts were dissolved in the solvents $\mathrm{MeOH}$ and $\mathrm{CHCl}_{3}$ to a final concentration of 30

Table 1. More Abundant Fragments Obtained via GC-MS

\begin{tabular}{lc}
\hline $\mathrm{R}_{t}$ (minutes) & More abundant fragments \\
\hline 10.39 & $118 ; 57 ; 41$ \\
8.89 & $87 ; 43$ \\
7.96 & 43 \\
7.58 & $97 ; 43$ \\
7.38 & $63 ; 57 ; 41$ \\
7.19 & $99 ; 43$ \\
6.97 & $87 ; 43$ \\
5.43 & $101 ; 43$ \\
4.59 & $59 ; 55 ; 43 ; 41$ \\
4.37 & $57 ; 43$
\end{tabular}




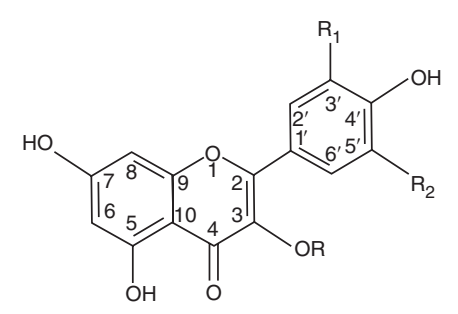

\begin{tabular}{|c|c|c|c|c|c|c|}
\hline & $\mathbf{R}$ & $R_{1}$ & $\mathbf{R}_{2}$ & & $\mathbf{R}$ & $\mathbf{R}_{1}$ \\
\hline (3) & Rha-(2" $\rightarrow 1$ "')-xyl; & $\mathrm{OH}$; & $\mathrm{H}$ & (9) & $\operatorname{Ara}(\mathrm{f})$ & $\mathrm{OH}$; \\
\hline (4) & Rha; & $\mathrm{OH}$; & $\mathrm{H}$ & (10) & $\alpha-\operatorname{Ara}(p)$ & $\mathrm{OH}$; \\
\hline (5) & Rha; & $\mathrm{OH}$; & $\mathrm{OH}$ & (11) & $\beta-\operatorname{Ara}(\mathrm{p})$ & $\mathrm{OH}$; \\
\hline (6) & Glc; & $\mathrm{OH}$; & $\mathrm{H}$ & (12) & Gal; & $\mathrm{OH}$; \\
\hline (7) & Glc (6"-cou); & $\mathrm{H}$ & $\mathrm{H}$ & (13) & Gal-(4" $\rightarrow 1$ " ')-rha; & $\mathrm{OH}$; \\
\hline (8) & Rha-(2" $\rightarrow 1 ")-x y l$; & $\mathrm{OH}$; & $\mathrm{OH}$ & & & \\
\hline
\end{tabular}

FIG. 4. Glycosylated flavonoids of Miconia species.

$\mathrm{mg} / \mathrm{mL}$. Then they were sterilized by filtration through 0.45 $\mu \mathrm{m}$ (pore size) Millipore filters. Antimicrobial tests were carried out using the disc-diffusion method. ${ }^{13}$ The microorganism cultures were grown in brain-heart infusion liquid medium at $37^{\circ} \mathrm{C}$. After 6 hours of growth, each microorganism culture, at a concentration of $10^{6}$ cells $/ \mathrm{mL}$, was inoculated onto the surface of Mueller-Hinton agar plates (100 $\mu \mathrm{L})$. Subsequently, filter paper discs (6 $\mathrm{mm}$ in diameter) saturated with extracts $(20 \mu \mathrm{L})$ were placed on the surface of each inoculated plate, onto the brain-heart infusion solid medium. The plates were incubated at $35^{\circ} \mathrm{C}$ for 24 hours for bacterial inoculations and for 48 hours for C. albicans. After this period, the zones of growth inhibition around the discs were measured. Overall, cultured microorganisms with halos greater than of equal to $7 \mathrm{~mm}$ were considered susceptible to the tested extract. The negative control was the solvent used, and the positive control was ciprofloxacin (5 $\mu \mathrm{g}$ per disc) for bacteria and ketoconazole (40 $\mu \mathrm{g}$ per disc) for $C$. albicans. All determinations were done in duplicate.

\section{Minimum inhibitory concentration (MIC)}

The MIC was determined by the dilution method according to the National Committee for Clinical Laboratory Standards. ${ }^{14}$ The bacteria were grown in nutrient broth (brain-heart infusion liquid medium) for 6 hours. After that, $20 \mu \mathrm{L}$ of $10^{6}$ cells $/ \mathrm{mL}$ was inoculated into tubes with nutrient broth supplemented with eight different concentrations $(25,50,100,200,400,500,600$, and $800 \mu \mathrm{L})$ of the extracts. After 24 hours at $37^{\circ} \mathrm{C}$, the MIC of each sample was measured from the optical density measured by the spectrophotometer $(620 \mathrm{~nm})$, by comparing the sample readout with that of the noninoculated nutrient broth. ${ }^{15}$ All determinations were done in duplicate.

\section{RESULTS}

Fractionation of the $\mathrm{MeOH}$ extract from M. cabucu led to the isolation of the biflavonoid 5-hydroxy-4',7dimethoxyflavone-(6-C-6")-5"-hydroxy-3"', $4^{\prime \prime \prime}, 7^{\prime \prime}$-trimethoxyflavone (1), gallic acid (2), and the flavonoids quercetin-3- $O$ - $\beta$-xyllopyranosyl-( $(1 \rightarrow 2)-O$ - $\alpha$-rhamnopyranoside (3), quercetin-3- $O$ - $\alpha$-rhamnopyranoside (4), myricetin3 - $O$ - $\alpha$-rhamnopyranoside (5), quercetin-3- $O$ - $\beta$-glucopyranoside (6), kaempferol-3-O- $\beta$-(6"-coumaroyl)-glucopyranoside (7), and myricetin-3- $O-\beta$-xyllopyranosyl- $(1 \rightarrow 2)-O-\alpha$-rhamnopyranoside (8) as reported in the literature. ${ }^{8}$ The study of $M$. rubiginosa led to the identification of gallic acid (2), quercetin-3- $O-\alpha$-rhamnopyranoside (4), quercetin-3-O- $\beta$ arabinofuranoside (9), quercetin-3- $O$ - $\alpha$-arabinopyranoside (10), quercetin-3- $O-\beta$-arabinopyranoside (11), quercetin-3$O$ - $\beta$-galactopyranoside (12), quercetin-3- $O-\alpha$-rhamnopyranosil- $(1 \rightarrow 4)-O-\beta$-galactopyranoside $(\mathbf{1 3})$, and epicatechin (14) (J. Rodrigues et al., unpublished data). The structures of these compounds are shown in Figure 4.

The $\mathrm{MeOH}$ extract of M. stenostachya was not fully studied, but the chromatographic profiles of the three species (Fig. 1) indicated that the flavonoidic profile of $M$. rubiginosa is closer to that of M. stenostachya and rather different from that of $M$. cabucu.

Table 2. Antimicrobial Activities of $\mathrm{CHCl}_{3}$ and $\mathrm{MeOH}$ Extracts of the Miconia Species

\begin{tabular}{|c|c|c|c|c|c|c|c|c|c|}
\hline \multirow[b]{2}{*}{ Extract } & \multicolumn{9}{|c|}{ Diameter of zone of inhibition $(\mathrm{mm})$ for microorganism } \\
\hline & S. epidermidis & C. albicans & S. aureus & M. luteus & E. faecalis & B. subtilis & B. cereus & E. coli & Salmonella \\
\hline \multicolumn{10}{|l|}{ M. саbucu } \\
\hline $\mathrm{MeOH}$ & - & - & - & - & - & - & - & - & - \\
\hline $\mathrm{CHCl}_{3}$ & 9 & 9 & 7 & - & - & - & - & - & - \\
\hline \multicolumn{10}{|c|}{ M. stenostachya } \\
\hline $\mathrm{MeOH}$ & 14 & 9 & 9 & 9 & - & 18 & 8 & - & - \\
\hline $\mathrm{CHCl}_{3}$ & - & - & - & - & - & - & - & - & - \\
\hline \multicolumn{10}{|l|}{ M. rubiginosa } \\
\hline $\mathrm{MeOH}$ & 9 & 8 & 10 & 10 & - & 9 & 8 & - & - \\
\hline $\mathrm{CHCl}_{3}$ & - & - & - & - & - & - & - & - & - \\
\hline Ciprofloxacin & 25 & NT & 25 & 20 & 22 & 20 & 20 & 22 & 22 \\
\hline Ketoconazole & NT & 16 & NT & NT & NT & NT & NT & NT & NT \\
\hline
\end{tabular}

$(-)$, negative; NT, not tested. 
Table 3. MiC Exhibited by Extracts of Miconia Species

\begin{tabular}{|c|c|c|c|c|c|c|}
\hline \multirow[b]{2}{*}{ Extract } & \multicolumn{6}{|c|}{ MIC $(\mathrm{mg} / \mathrm{mL})$ for microorganism } \\
\hline & S. epidermidis & C. albicans & S. aureus & M. luteus & B. subtilis & B. cereus \\
\hline M. сависи $\mathrm{CHCl}_{3}$ & $>10$ & 1.5 & 7.5 & NT & NT & NT \\
\hline M. stenostachya $\mathrm{MeOH}$ & 7.5 & 7.5 & 6.0 & 7.5 & 6.0 & 3.0 \\
\hline M. rubiginosa $\mathrm{MeOH}$ & $>10$ & $>10$ & $>10$ & $>10$ & 7.5 & 7.5 \\
\hline
\end{tabular}

NT, not tested.

The GC analysis of the chloroformic extracts showed that the three species studied have the similar secondary metabolites, e.g., aliphatic hydrocarbons, but in different amounts (Fig. 3).

A total of nine microorganisms, which consisted of eight bacteria and one yeast, were tested, and the results are summarized in Tables 2 and 3. The $\mathrm{CHCl}_{3}$ extract from $\mathrm{M}$. rubiginosa and $M$. stenostachya leaves did not show any activity; however, M. cabucu showed good activity against the microorganisms tested. The $\mathrm{MeOH}$ extract from M. rubiginosa and M. stenostachya leaves showed good antimicrobial activity against the microorganisms tested; however, the $\mathrm{MeOH}$ extract from $M$. сариси did not show any activity. In the assays against the microorganisms using the agar-diffusion method, the mean zones of inhibition obtained were between 7 and $18 \mathrm{~mm}$ (Table 2).

The $\mathrm{MeOH}$ extracts from $M$. rubiginosa and M. stenostachya leaves were active against $S$. epidermidis, $C$. albicans, S. aureus, M. luteus, B. subtilis, and B. cereus. We also observed antimicrobial activity of the $\mathrm{CHCl}_{3}$ extract from M. cabucu against S. epidermidis, C. albicans, and $S$. aureus. The MIC values obtained ranged between 1.5 and $10.0 \mathrm{mg} / \mathrm{mL}$ (Table 3). The best results were observed for the $\mathrm{CHCl}_{3}$ extract from $M$. cabucu against $C$. albicans, with an $\mathrm{MIC}$ at $1.5 \mathrm{mg} / \mathrm{mL}$, and the $\mathrm{MeOH}$ extract from $M$. stenostachya, showing activity against $B$. cereus at an MIC of $3.0 \mathrm{mg} / \mathrm{mL}$.

\section{DISCUSSION}

Tannins, gallic acid, some catechins, flavonoids, and terpenoids can show antimicrobial activity. ${ }^{16-19}$ Many works argue for the use of flavonoids against bacterial, protozoan, and fungal infections. Many of the bacterial strains commonly encountered by humans are killed by flavonoids. However, the mechanism by which this is accomplished is not known yet. ${ }^{20}$ In contrast, Chanwitheesuk et al. ${ }^{21}$ have demonstrated the action of gallic acid against Salmonella typhi and S. aureus.

The study of the Miconia $\mathrm{CHCl}_{3}$ extracts has revealed the presence of triterpenes and hydrocarbons. The antimicrobial activity observed can be explained by the presence of a mixture of substances, including triterpenes, with antimicrobial properties. ${ }^{22}$ The difference between the extract of $M$. cabucu and those of $M$. rubiginosa and $M$. stenostachya is the concentration of the substances, as shown in Figures 2 and 3.
The presence of flavonoids in the $\mathrm{MeOH}$ extracts from $M$. rubiginosa and $M$. stenostachya might be responsible for the antimicrobial activity. The different $R_{\mathrm{t}}$ values of the flavonoids of $M$. саbucu (Fig. 1) may explain the absence of activity for its extract.

The quality and quantity of the safety data on herbal drugs are far from sufficient to meet the criteria needed to support their use worldwide. Therefore, the reasons for the lack of research data are due not only to health care policies, but also to a lack of adequate or accepted research methodology for evaluating medicinal plants.

Solutions of the standardized extracts were prepared as described above before to the application to the Petri dishes. The antimicrobial activity was determined by visual and caliper measure of the sample zone diameters. Semiquantitative antimicrobial activity is among the most suitable techniques available for analysis in the quality control of antimicrobial herbal drugs.

Some differences can be found among different techniques used to determine the zone of inhibition. Also, it is possible to find some differences cited in the literature about antimicrobial activity of medicinal plants due to localization of the herbal drug where collected, season, extract preparation, solvent, and temperature, among others.

Our group had checked activity of $\mathrm{CHCl}_{3}$ and $\mathrm{MeOH}$ extracts using the disc-diffusion method and MIC according to the National Committee for Clinical Laboratory Standards. ${ }^{14}$ However, Celotto et al. ${ }^{22}$ used $20 \mu \mathrm{L}$ of ethanol extract by using the well-diffusion method. We could observe that the $\mathrm{MeOH}$ extract presents higher antimicrobial activity compared with extracts prepared with less polar solvents.

The results obtained in this study indicate that $M$. саbucu, M. rubiginosa, and M. stenostachya can be a useful source in the search for extracts and compounds with antimicrobial activity.

\section{ACKNOWLEDGMENTS}

This work was supported by funds from PADC-FCF, CAPES, FAPESP, and CNPq-Brazil.

\section{REFERENCES}

1. Renner SS: Phylogeny and classification of the Melastomataceae and Memecylaceae. Nord J Bot 1993;13:519-540. 
2. Almeida SP, Proença CEB, Sano SM, Ribeiro JF: Cerrado: Espécies Vegetais Úteis. EMBRAPA, Planaltina, DF, Brazil, 1998.

3. Hasrat JA, De Backer JP, Valquelin G, Vlietinck AJ: Medicinal plants in Suriname: screening of plants extracts for receptobinding activity. Phytomedicine 1997;4:56-65.

4. Cunha WR, Martins C, Ferreira DS, Crotti AEM, Lopes NP, Albuquerque $\mathrm{S}$ : In vitro trypanocidal activity of triterpenes from $\mathrm{Mi}$ conia species. Planta Med 2003;69:468-470.

5. Chan WR, Sheppard V, Medford KA, Tinto WF: Triterpenes from Miconia stenostachya. J Nat Prod 1992;55:963-966.

6. Macari PAT, Emerenciano VP, Ferreira ZMGS: Identification of triterpenes from Miconia albicans through analysis by microcomputer. Quim Nova 1990;13:260-262.

7. Li X-C, Jacob MR, Pasco DS, ElSohly HN, Nimrod AC, Walker LA, Clark AM: Phenolic compounds from Miconia myriantha inhibiting Candida aspartic proteases. I Nat Prod 2001;64: 1282-1285.

8. Rodrigues J, Rinaldo D, dos Santos LC, Vilegas W: An unusual $\mathrm{C}_{6}-\mathrm{C}_{6^{\prime \prime}}$ linked flavonoid of Miconia cabucu (Melastomataceae). Phytochemistry 2007;68:1781-1784.

9. Bernays E, Lupi A, Bettolo RM, Mastrofrancesco C, Tagliatesta $\mathrm{P}$ : Antifeedant nature of the quinone primin and its quinol miconidin from Miconia spp. Experientia 1984;40:10101011.

10. Mabry TJ, Markham KR, Thomas MB: The Systematic Identification of Flavonoids. Springer-Verlag, New York, 1970.

11. Silverstein RM, Bassler GC, Morrill TC: Spectrometric Identification of Organic Compounds. John Wiley \& Sons, New York, 1981.
12. Kitson FG, Larsen BS, McEwen CN: Gas Chromatography and Mass Spectrometry: A Practical Guide. Academic Press, San Diego, CA, 1996.

13. Bauer AW, Kirby MDK, Sherries JC, Turck M: Antibiotic susceptibility testing by a standardized single disk method. Am J Clin Pathol 1966;45:493-496.

14. National Committee for Clinical Laboratory Standards: Performance Standards for Antimicrobial Disc Susceptibility Tests. Approved Standard M2-A7. NCCLS, Wayne, PA, 2003.

15. Nascimento GGF, Locatelli J, Freitas PC, Silva GL: Antibacterial activity of plant extracts and phytochemicals on antibiotic-resistant bacteria. Braz J Microbiol 2000;31:247-256.

16. Scalbert A: Antimicrobial properties of tannins. Phytochemistry 1991;30:3875-3883.

17. Veluri R, Weir TL, Bais HP, Stermitz FR, Vivanco JM: Phytotoxic and antimicrobial activities of catechin derivatives. $\underline{\text { J Agric }}$ Food Chem 2004;52:1077-1082.

18. Bylka W, Matlawska I, Pilewski NA: Natural flavonoids as antimicrobial agents. J Am Nutraceut Assoc 2004;7:24-31.

19. Harborne JB, Williams CA: Advances in flavonoids research since 1992. Phytochemistry 2000;55:481-504.

20. Havsteen BH: The biochemistry and medical significance of the flavonoids. Pharmacol Ther 2002;96:67-202.

21. Chanwitheesuk A, Teerawutgulrag A, Kilburn JD, Rakariyatham $\mathrm{N}$ : Antimicrobial gallic acid from Caesapinia mimosoides Lamk. Food Chem 2007;100:1044-1048.

22. Celotto AC, Nazario DZ, Spessoto MA, Martins CHG, Cunha WR: Evaluation of the in vitro antimicrobial activity of crude extracts of three Miconia species. Braz J Microbiol 2003;34:339-340. 


\section{This article has been cited by:}

1. Tatiana M. Souza-Moreira, Juliana A. Severi, Emerson Santos, Viviana Y.A. Silva, Wagner Vilegas, Hérida R.N. Salgado, Rosemeire C.L.R. Pietro. 2011. Chemical and Antidiarrheal Studies of Plinia cauliflora. Journal of Medicinal Food 14:12, 1590-1596. [Abstract] [Full Text HTML] [Full Text PDF] [Full Text PDF with Links]

2. Juliana Rodrigues, Daniel Rinaldo, Marcelo Aparecido da Silva, Lourdes Campaner dos Santos, Wagner Vilegas. 2011. Secondary Metabolites of Miconia rubiginosa. Journal of Medicinal Food 14:7-8, 834-839. [Abstract] [Full Text HTML] [Full Text PDF] [Full Text PDF with Links]

3. Tatiana M. Souza-Moreira, Luiz Estêvão Salvagnini, Emerson Santos, Viviana Y.A. Silva, Raquel R.D. Moreira, Hérida R.N. Salgado, Rosemeire C.L.R. Pietro. 2011. Antidiarrheal Activity of Campomanesia xanthocarpa Fruit. Journal of Medicinal Food 14:5, 528-531. [Abstract] [Full Text HTML] [Full Text PDF] [Full Text PDF with Links]

4. Wilson R. Cunha, Geilton X. de Matos, Maria Goreti M. Souza, Marcos G. Tozatti, Márcio L. Andrade e Silva, Carlos H. G. Martins, Rosangela da Silva, Ademar A. Da Silva Filho. 2010. Evaluation of the antibacterial activity of the methylene chloride extract of Miconia ligustroides, isolated triterpene acids, and ursolic acid derivatives. Pharmaceutical Biology 48:2, 166-169. [CrossRef] 